\title{
Management of type Ia endoleak: Back to the future?
}

\author{
Giovanni Battista Luciani, MD
}

\author{
From the Division of Cardiac Surgery, Department of Surgery, Dentistry, Pediatrics, and Obstetrics/Gynecology, \\ University of Verona, Verona, Italy. \\ Disclosures: Author has nothing to disclose with regard to commercial support. \\ Received for publication Dec 14, 2017; accepted for publication Dec 21, 2017; available ahead of print Jan 19 , \\ 2018. \\ Address for reprints: Giovanni Battista Luciani, MD, Division of Cardiac Surgery, Department of Surgery, \\ Dentistry, Paediatrics, and Obstetrics/Gynaecology, University of Verona, O. C. M. Piazzale Stefani 1, Verona, \\ 37126 Italy (E-mail: giovanni.luciani@univr.it). \\ J Thorac Cardiovasc Surg 2018;155:1397-8 \\ $0022-5223 / \$ 36.00$ \\ Copyright (C) 2018 by The American Association for Thoracic Surgery \\ https://doi.org/10.1016/j.jtcvs.2017.12.102
}

Thoracic aortic endovascular repair (TEVAR) has become the mainstay treatment for most descending thoracic aortic disease conditions. ${ }^{1}$ Recent application of TEVAR in select patients with ascending aortic and arch lesions allows us to envision, in the near future, the goal of complete transcatheter management of any aortic pathology involving the aortic root, ascending aorta, and transverse arch. ${ }^{2-5}$

The study by Qi and associates ${ }^{6}$ from the Beijing Aortic Disease Center reminds our surgical community of the postulate that technology and scientific progress can only exchange one disease condition, burdened by a grave prognosis, with a different one associated with a more favorable outlook. Corollary to this postulate is that any cardiovascular treatment, including less-invasive treatment, is by definition palliative in that it will introduce new complications. Indeed, type Ia endoleak has emerged as the most taxing complication affecting as many as one third of patients late after TEVAR and representing an independent risk factor for mortality. ${ }^{7}$ Whereas additional endograft extension with or without hybrid aortic arch replacement has been applied to treat type Ia endoleak after descending thoracic endovascular repair with variable success, Qi and colleagues ${ }^{6}$ report on a select series of patients with chronic type $\mathrm{B}$ dissection who were managed by an open surgical repair, the stented elephant trunk procedure. With the use of a self-expandable stented graft manufactured in China, the authors were successful in eliminating the endoleak in all patients and promoting false lumen thrombosis in most. Associated ascending aortic and transverse aortic arch lesions also could be managed concomitantly, as illustrated in the elegant video submitted. The early and late outcomes were certainly remarkable, considering the severity of the underlying disease condition. However, some concern remains on the possibility of extending the stented elephant trunk procedure approach to most patients with type Ia endoleak after TEVAR involving the distal aortic arch, because the inclusion criteria of the study were rather vague and the

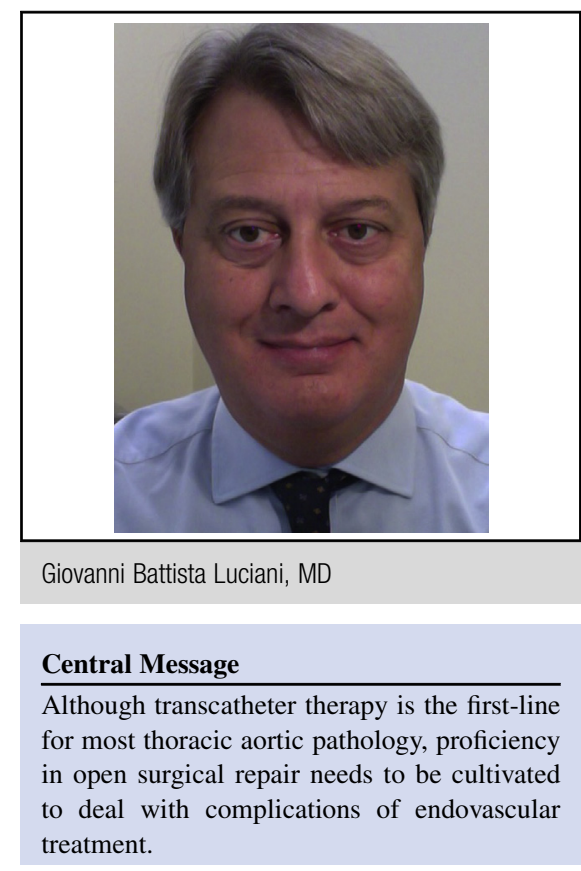

See Article page 1391.

population reported was evidently younger than in most TEVAR series.

Perhaps the most compelling message, which stems from the present report, is the necessity for cardiovascular surgeons to maintain the skills to deal with complications of transcatheter therapies. Because many native or postoperative structural disorders of the heart and vessels, including aortic, valvular, and congenital pathology, are destined to undergo a first-line catheter-based approach, early and late sequelae, some yet unprecedented, are bound to increase. Therefore, the surgical community faces a demanding responsibility. This will consist not so much in diverting young physicians toward interventional cardiology or radiology, but rather in fostering advanced training of, perhaps fewer, yet certainly more proficient surgeons with robust competence in the management of structural cardiovascular disease.

\section{References}

1. Fattori R, Montgomery D, Lovato L, Kische S, Di Eusanio M, Ince H, et al Survival after endovascular therapy in patients with type B aortic dissection: a report from the International Registry of Acute Aortic Dissection (IRAD). JACC Cardiovasc Interv. 2013;6:876-82.

2. Roselli EE, Idrees J, Greenberg RK, Johnston DR, Lytle BW. Endovascular stent grafting for ascending aorta repair in high-risk patients. J Thorac Cardiovasc Surg. 2015;149:144-51. 
3. Muetterties C, Menon R, Wheatley G. Ascending TEVAR: a systematic review of isolated endovascular repair of the ascending aorta. J Vasc Surg. 2016;63:152S-3S.

4. Bernardes RC, Navarro TP, Reis FR, Lima LC, Monteiro EL, Procopio RJ, et al. Early experience with off-the-shelf endografts using a zone 0 proximal landing site to treat the ascending aorta and arch. J Thorac Cardiovasc Surg. 2014;148:105-12. 5. Haulon S, Greenberg RK, Spear R, Eagleton M, Abraham C, Lioupis C, et al. Global experience with an inner branched arch endograft. J Thorac Cardiovasc Surg. 2014;148:1709-16
6. Qi R-D, Zhu J-M, Liu Y-M, Chen L, Li C-N, Xing X-Y, et al. The repair of a type Ia endoleak following thoracic endovascular aortic repair using a stented elephant trunk procedure. J Thorac Cardiovasc Surg. 2018;155: 1391-6.

7. Khoynezhad A, Donayre CE, Smith J, Kopchok GE, Walot I, White RA. Risk factors for early and late mortality after thoracic endovascular aortic repair. J Thorac Cardiovasc Surg. 2008;135:1103-9. 